\title{
DETERMINANTS OF ECONOMIC SUSTAINABILITY IN HIGHER EDUCATION INSTITUTIONS
}

\author{
Juraj Chebeň ${ }^{1}$, Drahoslav Lančarič ${ }^{2 *}$, Michal Munk ${ }^{3}$ and Peter Obdržálek ${ }^{4}$ \\ ${ }^{1)}$ University College of Business in Prague, Czech Republic \\ ${ }^{2)}$ Slovak University of Agriculture in Nitra, Slovakia \\ ${ }^{3)}$ University of Constantine the Philosopher in Nitra, Slovakia \\ ${ }^{4)}$ Comenius University in Bratislava, Slovakia
}

Please cite this article as:

Chebeň, J., Lančarič, D., Munk, M. and Obdržálek, P., 2020. Determinants of Economic Sustainability in

Higher Education Institutions. Amfiteatru Economic, 22(54), pp. 462-479.

DOI: $10.24818 / \mathrm{EA} / 2020 / 54 / 462$
Article History

Received: 30 December 2019

Revised: 26 January 2020

Accepted: 9 March 2020

\begin{abstract}
Despite the attention being paid to the environmental and social dimension of sustainability of Higher Education Institution (HEI) in the literature, little empirical research has focused on economic sustainability considering the HEI as an entity depending on financial funds provided by students, research, strategic partners, effective and efficient financial management. The conducted empirical survey deals with the link between the performance of HEI (number of students and the research productivity) and its economic sustainability measured as the average share of government subsidy. Furthermore, based on the 4678 students' questionnaires, the paper explores the perception of the quality of study and the capabilities of graduates of public HEIs in Slovakia. The authors have used Multivariate Tests of Significance to evaluate the influence of above-mentioned variables on the economic sustainability of HEIs. Based on the results it can be concluded the HEIs economic sustainability is directly determined by the number of enrolled students and research productivity, while the effect of the quality of study and the capabilities of graduates was not confirmed. Many HEI funding systems are based on the number of enrolled students. The funding system in Slovakia is one of them. Therefore, the results (even if drawing from the specific context) are widely applicable.

The study theoretically contributes to the sustainability of HEI by proposing a general and a specific conceptual model of sustainability in HEI. Some HEI funding systems based on the number of enrolled students are planning to base their funding system on capabilities of graduates and their employability (e.g. Slovakia). This fact even highlights the real-life importance of our study. Research results also tell that the quality of study and the capabilities of graduates are perceived differently at the altered types of HEI. Several HEIs were identified and therefore, HEIs need to adopt different strategies to satisfy diverse stakeholders' expectations.
\end{abstract}

Keywords: Higher Education Institution (HEI), sustainability, number of students, research productivity, quality of study, capabilities of graduates

JEL Classification: M1, P46, I25, H52, P36

* Corresponding author, Drahoslav Lančarič - lancaric.drahoslav@ gmail.com 


\section{Introduction}

The concepts of "sustainability" and sustainable development began to be used in United Nations document in the 1970s, especially in the context of knowledge, eco-development, limited resources and uncontrolled growth of any kind (population, production, consumption, pollution, etc). A high significance of sustainability in the education sector was also declared in many official documents listed in Casarejos, et al. (2017), Alghamdi, et al. (2017) and Zainordin and Ismail (2018). Over 25 official international declarations prove high importance of sustainable HEI. Sustainable development is the biggest challenge to HEIs in the twenty-first century and various HEIs have already become engaged in the process of integrating sustainable development in their activities (Weenen, 2000 , p.20). The study of sustainability in the context of higher education still remains as an emerging area of research of extreme importance. Most of HEI managements are unaware or ignorant of sustainability principles in the HEI setting (Lozano, 2006). Faculty and staff need sustainable development knowledge, but this necessity differs depending on the country and region (Sammalisto, et al., 2015).

While in 2010 the sustainability in higher education was an emerging field and a lot of research needed to be done to investigate the perceptions of major stakeholders within the HEI as well as applying sustainability in HEI (Wright, 2010), a year later Velazquez, et al. (2006) applied the sustainability in the HEI context within the areas of teaching, research, outreach and partnership, and in-campus sustainably practices. They developed the model of sustainable HEI that we are not trying to copy but to improve or add different features in it. The model does not contain important factors that can also determine the sustainability of HEI such as capabilities of graduates, quality of education and academic research, financial HEI management, and membership in strategic alliances. Weenen (2000) pointed out the importance of HEI's mission, research, education and operation in order to create sustainable HEI. According to De Araújo Góes, et al. (2016), HEIs proceed towards sustainability in several countries. While models proposed by Velazquez, et al. (2006) and Alghamdi, et al. (2017) focused on the integration of sustainability principles into education, research, partnerships and campus life, we are trying to show the reverse process and point out the financial dimension of sustainability. Aleixo, et al. (2018) researched different dimensions of sustainability (environmental, economic, social/ cultural, institutional/political/educational) in Portuguese HEIs, but in the economic dimension, they focused mainly on financial management, energy savings and gaining income from HEI's business activities. More exhaustive is the study of Blanco-Portela, et al. (2017) who presented the sustainability driver's model that supports our research model. In our study, we are focusing on the economic aspect of sustainability rather than social and environmental aspects as most HEIs described by Weenen (2000) did. HEIs implement sustainability into their organizational systems, research, operations, outreach, education, assessment and reporting (Cortese, 2003). The study of Casarejos, et al. (2017, p.999) presents an exhaustive list of different assessment frameworks for sustainability in HEI. The environmental part of the sustainability (with aims to provide a clean environment, to reduce the pollution, to save energies and to reduce emissions and waste), the social part of the sustainability (encourage social responsibility, labor practices, product responsibility, human rights, as well as to get actively involved in well-being of the society), the educational part of the sustainability (sustainability-related courses and research in sustainability) are central to HEIs and related to the economic sustainability, but based on our experiences the most important is the economic dimension of sustainability. 
The sustainability assessment tools (SAT) review and their analysis was central to an exhaustive research by Findler, et al. (2019) who found out that HEIs focused on internal operations when adopting sustainable development approach while they neglected the impacts from external environment, especially economic dimension of the sustainability. Even in another deep analysis of different assessment tools for sustainability in HEI by Zainordin and Ismail (2018) we do not see a model that would focus only on economic sustainability. Most of the models underestimate the economic dimension of sustainability.

Our study contributes to filling the gap in the sustainability development in HEI from the economic point of view and we have suggested a general and specific model of HEI's economic sustainability. General model is based on experiences, observation, interviews with top managers of 15 HEIs all over the world, and published research, while specific model links number of enrolled students, capabilities of graduates, employability of graduates, productivity of academic research, and financial funds in the context of quality of education, HEI reputation, and HEI budget. This study has relevant managerial implications. The paper is structured as follows: first, a literature review on factors affecting sustainability in HEI, then a conceptual framework and hypotheses in the methodological part including the sample, operationalization and analytical methods. Finally, results, discussion, and conclusions are presented.

\section{Review of the scientific literature}

HEIs are trying to successfully implement principles of sustainable development in their core activities such as education, research, operations, institutional framework, assessment, HEI management and policies, campus and relations with different stakeholder groups (Dabija, et al., 2014). Some HEIs even create sustainability office in order to implement and coordinate sustainability within the institution (Sepasi, et al., 2017). Although some previous research has focused on the use of certain factors that influence HEI sustainability, we can hardly find research that would focus on the capabilities of graduates, academic research, number of students and other important factors within a sustainability framework in HE sector. Velazquez, et al., (2005) researched factors affecting the effectiveness of sustainability in HEIs, but we still see some vital factors missing in their analysis. We can see many different drivers and barriers of sustainability that interfere with sustainability presented by Blanco-Portela, et al., (2017) and which could be inspiring for HEIs management in order to achieve sustainable development. In this part of the paper, we would like to point out different factors that lead to economic sustainability of HEI from the researcher and also from a practitioner's point of view.

HEI vision, mission, and strategies bring students to HEI or retain them at HEI. Commitments to sustainability expressed through the adoption of various declarations are often not effective unless combined with other "internal" and "external" strategies (Dlouhá, et al., 2018). The mission is one of 6 most important factors that influence the adoption of sustainability at HEI and also the factor that distinguishes private and public HEIs' approach towards sustainability adoption (Sepasi, et al., 2017) and therefore we added vision, mission, policies, and strategies in our general model. HEI marketing activities and reputation are also vital in attracting students (Angulo Ruiz, et al; 2016) and making them to continue to study till their last year of master studies (Angulo Ruiz and Pergelova, 2013). 
We have inserted the membership in strategic alliance in the general model (figure 1) because of our experiences from University College of business in Prague which is a member of strategic alliance of 3 private HEIs. A merger of 2 private HEIs that created 1 private HEI called Ambis also exists (https://www.ambiscollege.com/about-us). Ambis is a part of the Cognos AG which is one of the largest private and independent education consortium in Germany operating more than 15 technical schools, colleges and higher education institutions in Germany, Czech Republic, Luxembourg and other countries (https://www.cognos-ag.de/cognos-companies/?lang=en). All 3 cases are evidence from Europe. Strategic ownership, merger and close cooperation saved the existence of 5 HEIs who were about to end their existence because of a lack of funds, accreditation about to expire, lack of students, outdated study program not diversified study programs, missing orientation towards practice and foreign markets. In the future, we expect even more strategic alliances, mergers or acquisitions in HEI market in order to increase the competitiveness of HEI. The situation might be similar to a business market where we witness mergers every month (the latest $£ 35$ bn merger of PSA and Fiat Chrysler). In order to achieve the sustainable development of HEI we also suggest close cooperation with the business sector and non-educational organizations. HEI mergers are one decisive strategy for responding to financial pressures and to changed competitive environments (Thomas and Chabotar, 2015) Mergers of HEIs were also suggested in Japan in 2001 by the Japanese minister of education (Yamamoto, 2004). HEIs enter into coalitions in order to discuss progress in sustainability implementation (Dlouhá, et al., 2018). In order to achieve longterm HEI competitiveness and sustainability Thomas and Chabotar (2015) concluded that many U.S. higher HEIs face a complex combination of competitive and financial sustainability challenges that demand a more deliberate and strategic orientation toward alliances. They suggest a proactive consideration of more assertive and intentional forms of collaboration and alliance. HEIs pursue cost savings, efficiencies and integrations via partner HEIs' complementary and/or supplementary "fits." Joint resources, platforms and technology substantially increase capacity, talent and functional expertise.

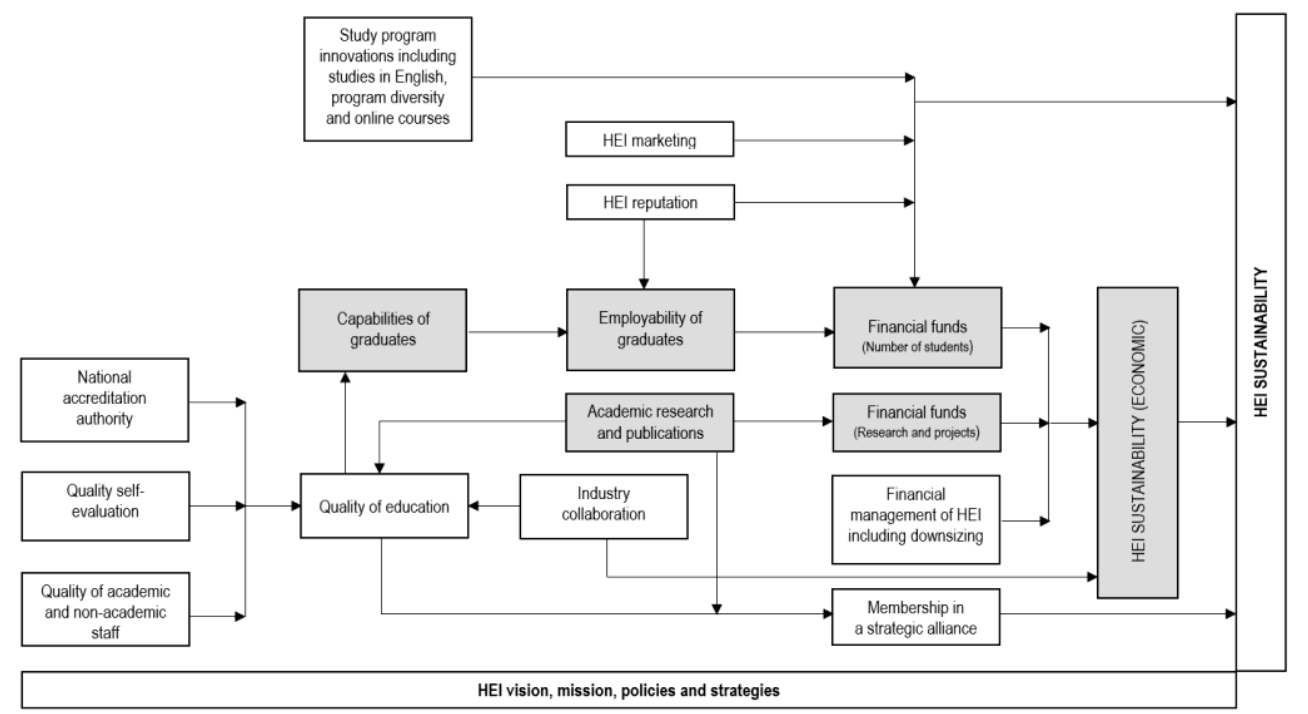

Figure no. 1: General Model of HEI Sustainability 
Industry collaboration might be another factor that supports the economic sustainability of the HEI. Thune (2011) focused the research on which potential success factors are relevant when developing and managing higher education-business partnerships. He found out that collaborative activities are probably important for HEIs since they have the ambition of being a central part in the regional innovation system. Cooperation with industry will contribute to the strengthening of the academic environment and to creating high quality and relevant study programs that are attractive to prospective students (Thune, 2011). Partnership working between HEIs and other organisations offers important opportunities for "adding value" and for promoting sustainability (Barnes and Phillips, 2000). Entrepreneurial activity should be stimulated and supported by HEI, and investments into human resources should not be underestimated because they are essential for attracting, developing and retaining them. In order to improve the sustainability, HEIs are advised to found start-up and spin-off companies which would support creating of a unique entrepreneurial ecosystem (Vekićet al; 2019).

Individual behaviour, conservative management, lack of incentives, and lack of financial resources are the main barriers to implement sustainability in HEIs (Blanco-Portela, et al., 2017). Irresponsible behaviour? Management that cannot flexibly adapt to changing environment? Incentives for improving the efficiency of the institution? The HEI's financial management is characterized by relative difficulty, as HEIs may have diversified financial resources to safeguard their various roles, with different regulations governing each financial resource. Public finances are ruled by the Budgetary Rules of the Statute, including EU subsidies, bilateral donation contracts cover donations, concluded by profiling tasks of HEIs, for the use of business profits are governed by the rules of the business project, which approved. Dr. Chebeň, former head of Senate in private HEI called Academy of Media Studies, has personal experiences from this area. Because of irresponsible leadership, suspicions financial management and wrong financial decisions, bad contracts and a lack of long-term focus this HEI bankrupted. The main problem was the management of HEI. Specific examples of irresponsible leadership are listed in Chebeň (2013). HEI's top managers, mainly bursar, dean, and rector must be well versed in the legal regulations of the state where the HEI resides. They are also required to suggest to the wider HEI management proposals for rational measures to deal with the HEI's finances. These should focus on the efficient spending of wages, contributions to insurance funds, inkind expenditures, including energy, telecommunications, travel expenses, property insurance, HEI's business activities, but also rational investments such as modernization and reconstruction. Particular attention should be paid to the cost of information technology. Based on the above-mentioned facts, our experiences and interviews with other top managers of different HEIs, financial HEI management is also included in the general model as it is crucial in HEI survival.

Downsizing is another (although dangerous) tool for improving efficiency and sustainability of the university (Yamamoto, 2004). As early as 2002, Appelbaum and Patton focused their research on downsizing at HEI's in order to increase efficiency and competitiveness. According to these authors downsizing at HEIs has specifics that have to be taken into account and the most suitable method would be to provide early retirement incentive programs. Downsizing aims to increase the productivity and according to Cudanov, et al. (2012), who suggested revising productivity especially in public organizations, this improved productivity can contribute to economic sustainability. Based on our 20-year observations and statistical data, downsizing has been observed in Slovakia 
since the year 2000, and it has been very visible since 2015. Even though the number of HEI's students in Slovakia has been showing a slight decrease, the number of staff has been dropping constantly and evidently.

HEIs must flexibly react to the situation on the educational market and act strategically with a long-term vision. The dynamics of society's development naturally force every individual to be flexible to continuous education. HEI are required to provide education services continuously, even in postgraduate learning, distance learning, lifelong learning of older or international students, and professional education for different organizations because as Brown (2001) revealed, increased reliance on either state or federal government funding is associated with teaching quality and student perceptions of teaching quality are significantly impacted by the source of educational funds and quality of education impacts career success of graduates (Teichler, 2009) and their employability (Farcnik and Domadenik, 2012).

\subsection{Quality of education and employability of graduates}

HEIs are the highest educational institutions in every state of the world. Their quality is guaranteed by the scientific board and by the Accreditation committee. Even the highest quality study program provided by progressive teaching methods and high-quality educators cannot guarantee $100 \%$ success of all HEI graduates in the job market. The quality of education in the relevant state must be a program and a goal at every level of education, beginning in kindergarten and ending with HEI, as well as continuing in specialized lifelong learning to dynamically change global living conditions. Graduates' abilities are directly proportional to the level of quality of teaching provided at all levels of education (smarter prospective students will perform better when goals and learning requirements are set on high level what consequently leads to smarter graduates), as well as to the natural individual dispositions of each individual, including their voluntary characteristics. Since 1990s the career success of graduates started to be used as a key indicator to measure the quality of education in general and higher education in particular (Teichler, 2009). An aspect of quality in higher education is the quality of the outcomes achieved. Higher education adds value by developing job-related skills and competencies (Woya, 2019). Students' competencies and students' chances of employment are positively and directly influenced by the quality of the educational process (represented by the quality of the content of the educational process, the quality of the teaching staff, and the quality of the teaching activities), and research activities (Gora, et al., 2019). Employability can provide relevant information regarding student's choice and a proxy measure for the quality of higher education (Farcnik and Domadenik, 2012).

\subsection{Number of students and study program innovations as an important determinant of economic sustainability}

HEIs must flexibly react to the situation on the educational market and act strategically with a long-term vision. The dynamics of society's development naturally force every individual to be flexible to continuous education. In many developed countries, demographics push HEIs to an unsustainable situation. As Aleixo, et al. (2016) found out, the lack of financial resources due to the decline in funding for higher education and the falling numbers of students in 
Portugal are the main barriers to the sustainability of HEIs. In order to balance the demographic decline of students and higher competition on the educational market, HEIs are also targeting students abroad. Attracting international students is one of HEI sustainability factors because it creates additional funds for the HEI. Slovakia enrolled $6.9 \%$ in 2017 of all admitted international students $(5.6 \%$ in 2015$)$ while Canada $12.9 \%$ in 2017 . When trying to attract all potential students and especially make companies to order services provided by HEI, HEI should communicate intensively with employers and reflect their demands. Capable and successful graduates remain of the best "promotion". Providing required and professional education can also ensure a continuous and sustainable source of income to HEI. Students are the main source of income of HEI and without reflecting the environmental and dynamically changing potential students' needs may be one of the factors influencing the sustainability of HEIs. Without taking advantage of environmental opportunities, HEIs can lose their competitiveness, students and will have to reduce staff to survive that can consequently lead to lower quality and even bigger loss of students. HEIs try to solve the situation differently. In order to increase revenue and reputation, HEIs engage in different study program innovation, dual degrees, study programs in foreign languages (mainly English, but also German, French, Spanish, Russian).

International students are "cash cows" (generating high profits) for many Australian, US, Canadian, but also European HEIs. Many documents published in web by Telegraph UK, ABC news, CBC Canada, and others talk about international students as a source of income. In a documentary by $\mathrm{ABC}$ news, assoc. prof. Gerd Schroder-Turk from Murdoch HEI (Australia) said: "financial position of Murdoch HEI was unsustainable and the change was necessary, so international students had to rectify the budget position". Findings from the study by Cantwell (2015) and Dabija, et al. (2017) also suggest that only HEIs that can attract large numbers of students from abroad stand to generate substantial revenue from international student fees. HEIs keep progressing towards the integration of sustainability, but to fully achieve the internationalization of sustainable practices, they need to modify the operating dynamics. Many HEIs try to attract international students offer massive open online courses (MOOC) that can also generate additional revenues (Epelboin, 2014) and spread HEI's brand. MOOC could be a useful tool to improve the sustainability when it is wisely managed. It might be a good tool that improves learning experiences. According to Ong and Grigoryan (2015) a MOOC provider offers students a collection of courses to take; but it does not offer students a degree that prospective employers and academia recognize and accept. HEIs must be also aware of the threat of competition of MOOCs. Program diversity is also an important goal because a diverse academic system should better satisfy public preferences and needs and lead to greater social and economic benefits for society (Dill and Teixeira, 2000). We would add that staff diversity could also add value to the quality of all activities provided by HEIs, especially when internationalization is a priority for HEI.

\subsection{Academic research and publications as a determinant of economic sustainability}

HEIs are not only the highest educational institutions but also the highest scientific institutions in all continents of the world. The high level of scientific research is supposed to be correlated with a high level of education quality. Another important factor of HEI sustainability is the research productivity (representing both the quality of the research outputs as well as their quantity). The research productivity of HEIs in Slovakia is most definitely not among the best, which results in the awarding of status „Research HEI” by 
the Ministry of Education, science, research and sport (MoESRS) only to 7 out of 20 public HEIs. It is partially caused by the social and economic development of Slovakia in the past, when the research productivity was not among the priorities of HEIs and partially by the low quality of the substantial part of tenure staff (Ciaian, et al., 2018) in some research areas. The newly formed Accreditation Agency in Slovakia sets higher standards for research productivity of academics at HEIs which might eventually lead to the decreased number of study programs (each study program has a guarantor who must fulfil research criteria set by Accreditation agency). This would be a welcomed development since there is very low or no demand for the graduates of many study programs on the labor market. Czech HEIs depend on grants and research activities (Pavelka, 2014) and we would say that the situation is similar in Slovakia (table no. 1).

Table no. 1: Share on financial funds generated by academic research (in \%)

\begin{tabular}{|l|c|c|c|c|c|c|c|c|c|c|c|}
\hline & $\mathbf{2 0 0 9}$ & $\mathbf{2 0 1 0}$ & $\mathbf{2 0 1 1}$ & $\mathbf{2 0 1 2}$ & $\mathbf{2 0 1 3}$ & $\mathbf{2 0 1 4}$ & $\mathbf{2 0 1 5}$ & $\mathbf{2 0 1 6}$ & $\mathbf{2 0 1 7}$ & $\mathbf{2 0 1 8}$ & $\mathbf{2 0 1 9}$ \\
\hline UK Bratislava & $\mathbf{2 2 . 9 5}$ & $\mathbf{2 2 . 5 0}$ & $\mathbf{2 3 . 0 6}$ & $\mathbf{2 3 . 2 2}$ & $\mathbf{2 3 . 1 9}$ & $\mathbf{2 5 . 6 0}$ & $\mathbf{2 3 . 7 4}$ & $\mathbf{2 3 . 8 4}$ & $\mathbf{2 5 . 0 4}$ & $\mathbf{2 5 . 0 4}$ & $\mathbf{2 3 . 5 5}$ \\
\hline UPJŠ Košice & $\mathbf{5 . 7 0}$ & $\mathbf{5 . 7 7}$ & $\mathbf{6 . 0 9}$ & $\mathbf{6 . 5 1}$ & $\mathbf{6 . 5 8}$ & $\mathbf{6 . 4 3}$ & $\mathbf{7 . 7 6}$ & $\mathbf{8 . 2 2}$ & $\mathbf{7 . 0 9}$ & $\mathbf{8 . 3 0}$ & $\mathbf{8 . 7 5}$ \\
\hline PU Prešov & 3.62 & 3.42 & 3.16 & 3.58 & 3.75 & 3.61 & 3.53 & 3.19 & 3.16 & 3.09 & 2.92 \\
\hline UCM Trnava & 1.05 & 1.05 & 1.07 & 1.38 & 1.55 & 1.50 & 1.48 & 1.72 & 1.79 & 1.64 & 1.62 \\
\hline UVL Košice & $\mathbf{2 . 5 1}$ & $\mathbf{2 . 0 5}$ & $\mathbf{2 . 2 7}$ & $\mathbf{1 . 9 6}$ & $\mathbf{2 . 0 3}$ & $\mathbf{2 . 3 2}$ & $\mathbf{1 . 9 0}$ & $\mathbf{1 . 7 6}$ & $\mathbf{1 . 7 5}$ & $\mathbf{1 . 7 5}$ & $\mathbf{1 . 7 1}$ \\
\hline UKF Nitra & 4.12 & 4.75 & 4.17 & 4.20 & 4.30 & 3.73 & 3.57 & 3.95 & 4.00 & 4.12 & 4.08 \\
\hline UMB B.Bystrica & 3.99 & 4.70 & 4.22 & 4.46 & 4.37 & 4.04 & 4.19 & 4.20 & 4.17 & 4.13 & 4.03 \\
\hline TvU Trnava & 2.35 & 2.40 & 2.21 & 2.22 & 2.28 & 2.12 & 1.96 & 2.42 & 2.32 & 2.22 & 2.22 \\
\hline STU Bratislava & $\mathbf{1 7 . 6 9}$ & $\mathbf{1 6 . 9 2}$ & $\mathbf{1 8 . 1 0}$ & $\mathbf{1 8 . 1 9}$ & $\mathbf{1 8 . 3 9}$ & $\mathbf{1 6 . 9 3}$ & $\mathbf{1 6 . 7 0}$ & $\mathbf{1 6 . 2 5}$ & $\mathbf{1 5 . 9 3}$ & $\mathbf{1 5 . 3 0}$ & $\mathbf{1 4 . 8 0}$ \\
\hline TU Košice & $\mathbf{9 . 8 3}$ & $\mathbf{8 . 9 0}$ & $\mathbf{9 . 3 1}$ & $\mathbf{9 . 0 2}$ & $\mathbf{8 . 9 6}$ & $\mathbf{9 . 7 5}$ & $\mathbf{1 0 . 0 1}$ & $\mathbf{1 0 . 2 3}$ & $\mathbf{1 0 . 1 9}$ & $\mathbf{9 . 3 6}$ & $\mathbf{9 . 3 8}$ \\
\hline ŽU Žilina & $\mathbf{5 . 9 3}$ & $\mathbf{7 . 0 4}$ & $\mathbf{7 . 1 2}$ & $\mathbf{6 . 5 5}$ & $\mathbf{6 . 2 5}$ & $\mathbf{6 . 6 0}$ & $\mathbf{7 . 7 9}$ & $\mathbf{7 . 6 5}$ & $\mathbf{7 . 4 7}$ & $\mathbf{7 . 4 5}$ & $\mathbf{7 . 7 0}$ \\
\hline TUAD Trenčín & 1.70 & 1.17 & 1.26 & 1.27 & 1.25 & 1.14 & 1.21 & 1.03 & 1.15 & 1.10 & 3.12 \\
\hline EU Bratislava & 4.19 & 4.44 & 3.90 & 4.02 & 3.81 & 3.44 & 3.68 & 3.17 & 3.18 & 3.52 & 3.22 \\
\hline SPU Nitra & $\mathbf{4 . 2 9}$ & $\mathbf{4 . 3 6}$ & $\mathbf{4 . 1 6}$ & $\mathbf{4 . 4 4}$ & $\mathbf{4 . 1 9}$ & $\mathbf{4 . 3 1}$ & $\mathbf{4 . 3 3}$ & $\mathbf{4 . 2 2}$ & $\mathbf{4 . 0 8}$ & $\mathbf{4 . 2 2}$ & $\mathbf{4 . 0 4}$ \\
\hline TU Zvolen & 3.05 & 2.93 & 2.78 & 2.50 & 2.71 & 2.47 & 2.33 & 2.83 & 2.88 & 2.91 & 3.21 \\
\hline VŠMU Bratislava & 1.95 & 1.87 & 1.87 & 1.62 & 1.69 & 1.52 & 1.23 & 1.12 & 1.78 & 1.94 & 1.96 \\
\hline VŠVU Bratislava & 1.20 & 1.52 & 1.51 & 1.26 & 1.14 & 1.16 & 1.39 & 1.12 & 1.02 & 1.11 & 1.01 \\
\hline AU B.Bystrica & 0.79 & 0.76 & 0.77 & 0.73 & 0.78 & 0.88 & 0.89 & 0.76 & 0.90 & 0.75 & 0.79 \\
\hline KU Ružomberok & 2.78 & 3.08 & 2.66 & 2.56 & 2.44 & 2.10 & 1.94 & 1.89 & 1.65 & 1.58 & 1.45 \\
\hline UJS Komárno & 0,32 & 0,36 & 0,31 & 0,31 & 0,34 & 0,36 & 0,38 & 0,43 & 0,44 & 0,47 & 0,44 \\
\hline
\end{tabular}

Note: The research HEIs are marked in grey

In Slovakia, there are HEIs that are more teaching orientated and HEIs that are more research orientated. "Research" orientated HEI usually gets more finances from State's budget than "teaching" orientated HEIs. In the methodological part of the paper we focus on specific sustainability model of HEI that leads to economic sustainability of HEI.

\section{Research Methodology}

Even if there is a substantial body of literature dealing with the different aspects of HEI sustainability (Fonseca, et al, 2011; Amaral, et al., 2015) there are no generally accepted 
quantitative indicators of sustainability (Fath, 2015; Hák, et al., 2016). In the case of HEI, there is a general agreement; the indicators should cover the entire system to address: education, research, campus operations, and community outreach (Cortese, 2003). In the paper we focus on two areas: education (number of students) and research (figure 2).

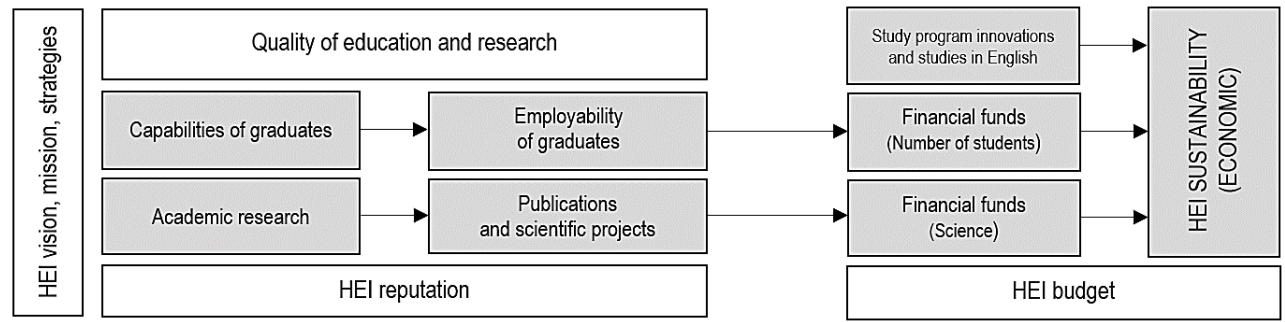

Figure no. 2: Specific Model of HEI s Economic Sustainability

We specifically deal with the economic sustainability of HEI. In the field of education, we quantify the HEI sustainability as an average share on the government subsidy on education in the period 2009-2019. In the field of research, we quantify the HEI sustainability as an average share on the government subsidy on research in the period 2009-2019. Using the both partial measures, a total HEI sustainability measure is derived (table 2). The quality of education is assessed by the Accreditation agency, an independent body of the MoESRS. The results are broadly communicated which contributes better HEI reputation. The HEI reputation might lead to an increased number of students (Budur, et al., 2018; Eger, et al., 2018). MoESRS awards the status of a research HEI. It represents the quality of HEI research calculated by using the number of researches, publications, projects and research areas. Both the number of students and the research productivity are the key indicators in any performance based HEI funding model (Jongbloed and Vossensteyn, 2016; Horn and Lee, 2019). State funding allocated through performance-based funding is more than merely a mechanism to allocate financial resources, it also provides a tool for institutional managers and policy makers to maximize desired outputs using incentives (Jongbloed 2010), thus contributing to overall sustainability of HEI. Based on the previous studies, we set up the following hypotheses:

Hypothesis 1: The economic sustainability of HEI is determined by the number of its students and the quality of research.

To evaluate the influence of selected determinants (Number of Students (NoS); Productivity of Research (PoR)) the authors used Multivariate Tests of Significance. The dependent variables are Economic sustainability of HEI (total; AVG_ST); Economic sustainability of HEI (education; AVG_SE); Economic sustainability of HEI (research and projects; AVG_SR). Independent variables are: Number of Students (NoS) and Productivity of Research (PoR).

Hypothesis 2: The economic sustainability of HEI is determined by the quality of study and capabilities of graduates.

To evaluate the influence of selected determinants (Quality of Study (QoS); Capabilities of Graduates $(\mathrm{CoG}))$ the authors used Multivariate Tests of Significance. The dependent variables are Economic sustainability of HEI (total; AVG_ST); Economic sustainability of HEI 
(education; AVG_SE); Economic sustainability of HEI (research and projects; AVG_SR). Independent variables are: Quality of Study (QoS); Capabilities of Graduates (CoG).

In order not to reduce the power of statistical tests, we verified the assumptions of multivariate and univariate significance tests. The homogeneity of the variance and covariance matrices was verified by a Sen and Puri`s non-parametric test with respect to the identification of deviations from normality. Multicollinearity of variables was verified by VIF score (VIF=1.55) which indicates some correlation, but without a negative effect on the model (Lavery, et al., 2019). The results of all multivariate significance tests (Pillai's Trace, Wilk's Lambda, Hotelling's Trace, Roy's Largest Root) were the same. However, we present only the results of Pillai`s Trace since it is the most robust of the multivariate significance tests, i.e. the most resistant to assumptions violation. We also verified the interaction effect between independent variables, and no significant effect was confirmed.

\subsection{Operationalization of the variables and data obtaining}

The operationalization of variables is shown in table 2. The data were obtained from two different sources. The data about HEI (subsidies and performance measures) are drawn from the MoESRS web site and are publicly available (https://www.minedu.sk/677sk/financovanie/). The data about the perception of the quality of study and the capabilities of graduates was obtained by the Centre of Educational Management of Comenius HEI via questionnaire. It was distributed with the support of MoESRS. It consisted of three major parts dealing with the characteristics of respondents, their motivation to study and their assessment of the study quality at the HEIs in Slovakia. For this study we focused on the third part of the questionnaire, which consists of the items dealing with the perception of the overall quality of HEI study and the capabilities of the graduates.

Table no. 2: The operationalization of the variables

\begin{tabular}{|l|l|l|}
\hline Variable & Coding & Measurement \\
\hline $\begin{array}{l}\text { Economic sustainability of HEI } \\
\text { (total) }\end{array}$ & AVG_ST & Average share of total government subsidy (2009-2019) in \% \\
\hline $\begin{array}{l}\text { Economic sustainability of HEI } \\
\text { (education) }\end{array}$ & AVG_SE & $\begin{array}{l}\text { Average share of government subsidy (2009-2019) in \% (for } \\
\text { education only) }\end{array}$ \\
\hline $\begin{array}{l}\text { Economic sustainability of HEI } \\
\text { (research and projects) }\end{array}$ & AVG_SR & $\begin{array}{l}\text { Average share of government subsidy (2009-2019) in \% (for } \\
\text { research only) }\end{array}$ \\
\hline Number of Students & NoS & $\begin{array}{l}\text { 1=over 15,000; } 2=10,001 \text { to } 15,000 ; 3=5,001 \text { to 10,000; } \\
\text { 4=5000 and less }\end{array}$ \\
\hline Productivity of Research & PoR & $\begin{array}{l}\text { Status of research HEI awarded by the Ministry of Education: } \\
1=\text { yes; 0=no }\end{array}$ \\
\hline Quality of Study & QoS & $\begin{array}{l}\text { Average score for items QoS_1 to QoS_14 } \\
\text { Likert scale; } 1=\text { totally agree; 5=totally disagree }\end{array}$ \\
\hline Capabilities of Graduates & CoG & $\begin{array}{l}\text { Average score for items CoG_1 to CoG_7 } \\
\text { Likert scale; } 1=\text { totally agree; 5= totally disagree }\end{array}$ \\
\hline
\end{tabular}

A survey was conducted on a sample of 4678 respondents studying at the Slovak public HEIs. Over $88 \%$ of the respondents do their studies in full-time form. The sample consists of students from 19 public HEIs in Slovakia, meaning only 1 HEI out of the total number of 20 is not represented. The sample is representative on the confidence level $99 \%$ with standard error of $1.6 \%$. Data was collected from the end of 2017 , but most of the data was collected in the first quarter of 2018. The reliability of the questionnaire was verified by means of Cronbach's alpha. There were 3 questionnaire items identified removal of which 
would increase the overall reliability of the questionnaire. However, the change in the Cronbach's alpha would be only marginal. With respect to results (Cronbach's alpha>0.7), we consider the reliability of the measurement instrument sufficient. The Intraclass Correlation Coefficient $(\mathrm{ICC}=0.83$ ) confirmed this conclusion.

\section{Results and Discussion}

\subsection{Sample characteristics}

Out of the total number of 4678 respondents the most numerous age group was the one including the respondents from "22 to 26 years" of age, accounting for $73.28 \%$ of the total number of respondents. Age group " 21 years and less" accounted for $10.24 \%$ and age group " 27 to 31 years" for $14.37 \%$ of the total number of respondents. The sample consisted of 1980 men $(42.33 \%)$ and $2698(57.67 \%)$ women. Almost 59\% of respondents do their studies on the bachelor level, $37 \%$ on the master level and $4 \%$ on the PhD level of study.

Figure 3 shows the HEI s profiles based on all three utilized sustainability measures: the total economic sustainability of HEI (AVG_ST) and both partial measures (AVG_SE; AVG_SR). The individual axes in the figure show the ratio of a sustainability measure to its maximum. It also visualizes variables quality of the study (QoS) and the capabilities of graduates $(\mathrm{CoG})$. As can be seen several HEIs (e.g. technological HEIs) have a very similar profile concerning the attitudes of the respondents towards the perception of the quality of their study as well as their capabilities.
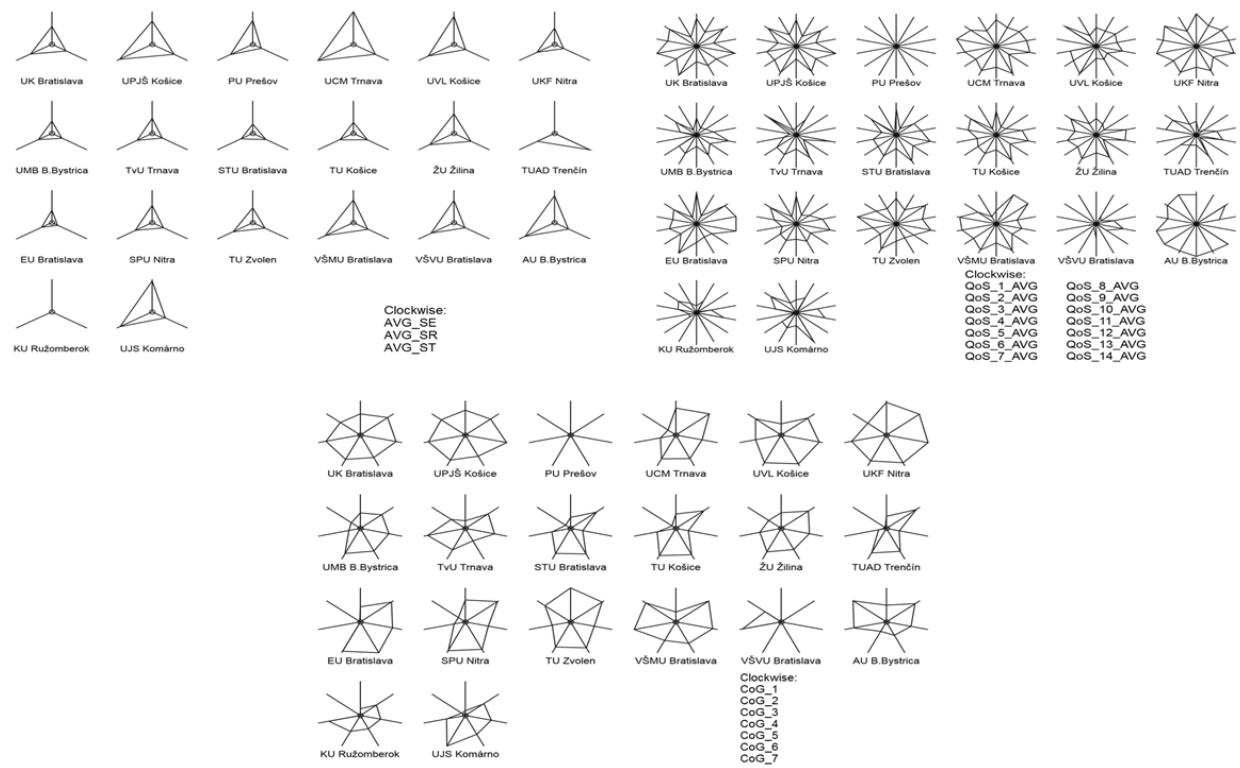

Figure no. 3: HEI s profiles 


\subsection{Number of Students and Quality of Research}

Performance-based funding is a system based on allocating a portion of a state's higher education budget according to specific performance measures such as course completion, credit attainment, and degree completion. Furthermore, this funding structure incorporates both enrolment and performance metrics as incentives for colleges to continue to make progress on these important objectives (Miao, 2012). It can be expected (Jongbloed, 2001) that the funds supplied out of the public purse are dependent on institutional performance, because this would be in line with ideologies that stress a more market-like approach to management (De Boer, et al., 2015) and budgeting throughout the whole of the public sector. There are several approaches to quantification of HEI performance. The Higher Education Funding Council for England (HEFCE) has published sets of higher education performance indicators (PIs) covering access, participation and progression (number of students), research and employability (Bratti, 2004). In our study, we narrowed the PIs down to the average number of students in years 2009-2019 (NoS) and the productivity of research (PoR). Both numbers of students and the quality of research are the key indicators evaluated by the national accreditation authority. In the model they are utilized as independent variables. As dependent variables the economic sustainability of HEI (total; AVG_ST); economic sustainability of HEI (education; AVG_SE) and economic sustainability of HEI (research and projects; AVG_SE) were utilized. Multivariate Tests of Significance were used as the evaluating method. Based on the results shown in Table 3 we conclude that the economic sustainability of HEI is directly determined by the number of enrolled students and the research performance. Hypothesis 1 was confirmed.

Table no. 3: Multivariate Tests of Significance - Pillai's trace statistic (NoS; PoR)

\begin{tabular}{|l|c|c|c|c|c|}
\hline Effect & Pillai's & F & Effect df & Error df & p level \\
\hline Intercept & 0.955 & 128.537 & 2 & 12 & $\mathrm{p}<0.001$ \\
\hline NoS & 1.230 & 6.928 & 6 & 26 & $\mathrm{p}<0.001$ \\
\hline PoR & 0.441 & 4.728 & 2 & 12 & $0.031^{*}$ \\
\hline
\end{tabular}

Table 4 further shows that the N_S and QoR significantly influence each sustainability indicator used. Based on the results several implications can be drawn for policy makers. The number of enrolled students is still one of the main factors by which the HEI budget is determined and therefore the economic sustainability achieved. It accounts for $65 \%$ of total government subsidy flowing to higher education in Slovakia while in Denmark, two-thirds of the state budget is based on research and one-third on teaching (Orr and Usher, 2018). Even if the total number of students studying at the public HEIs in Slovakia has decreased for over $37 \%$ in 2019 when compared to 2009 , the decrease of the total number of potential students is even higher. Therefore, HEIs are highly motivated to enrol students who would otherwise not be considered as "HEI material". The shift in the subsidy structure towards performance-based funding is long overdue.

Table no. 4: Tests of Between-Subjects Effects (NoS; PoR)

\begin{tabular}{|l|l|c|c|c|c|c|}
\hline \multirow{2}{*}{ Source } & \multicolumn{1}{|c|}{$\begin{array}{c}\text { Type III Sum } \\
\text { of Squares }\end{array}$} & df & Mean Square & F & p level \\
\hline \multirow{3}{*}{ Intercept } & AVG_ST & 1473.796 & 1 & 1473.796 & 276.375 & $\mathrm{p}<0.001$ \\
\cline { 2 - 7 } & AVG_SE & 666.370 & 1 & 666.370 & 278.392 & $\mathrm{p}<0.001$ \\
\cline { 2 - 7 } & AVG_SR & 158.154 & 1 & 158.154 & 254.494 & $\mathrm{p}<0.001$ \\
\hline
\end{tabular}




\begin{tabular}{|l|l|c|c|c|c|c|}
\hline \multicolumn{2}{|l|}{ Source } & $\begin{array}{c}\text { Type III Sum } \\
\text { of Squares }\end{array}$ & df & Mean Square & F & p level \\
\hline \multirow{3}{*}{ NoS } & AVG_ST & 472.221 & 3 & 157.407 & 29.518 & $\mathrm{p}<0.001$ \\
\cline { 2 - 7 } & AVG_SE & 178.662 & 3 & 59.554 & 24.880 & $\mathrm{p}<0.001$ \\
\cline { 2 - 7 } & AVG_SR & 70.374 & 3 & 23.458 & 37.748 & $\mathrm{p}<0.001$ \\
\hline \multirow{3}{*}{ PoR } & AVG_ST & 47.603 & 1 & 47.603 & 8.927 & $0.010^{*}$ \\
\cline { 2 - 8 } & AVG_SE & 19.423 & 1 & 19.423 & 8.114 & $0.014^{*}$ \\
\cline { 2 - 8 } & AVG_SR & 6.212 & 1 & 6.212 & 9.996 & $0.008^{* *}$ \\
\hline
\end{tabular}

Note: $* * * p<0.001 ; * * p<0.01 ; * p<0.05 ;$ NoS=number of students; PoR=productivity of research

We were interested in which size groups of HEIs there were statistically significant differences. We use HSD test for unequal $\mathrm{N}$ for multiple comparisons. We have identified two homogeneous groups: $(3,4)$ and $(3,2)$. A statistically significant difference at the $5 \%$ significance level was identified between category 4 and 2 and between category 1 and categories 2-4 (table 5).

Table no. 5: Multiple comparisons - HSD test (NoS)

\begin{tabular}{|c|c|c|c|c|c|c|c|c|c|c|c|c|}
\hline NoS & AVG_ST - Mean & $\mathbf{1}$ & $\mathbf{2}$ & $\mathbf{3}$ & AVG_SE - Mean & $\mathbf{1}$ & $\mathbf{2}$ & $\mathbf{3}$ & AVG_SR - Mean & $\mathbf{1}$ & $\mathbf{2}$ & $\mathbf{3}$ \\
\hline 4 & 0.024 & $*$ & & & 0.017 & $*$ & & & 0.007 & $*$ & & \\
\hline 3 & 0.056 & $*$ & $*$ & & 0.040 & $*$ & $*$ & & 0.016 & $*$ & $*$ & \\
\hline 2 & 0.084 & & $*$ & & 0.059 & & $*$ & & 0.024 & & $*$ & \\
\hline 1 & 0.256 & & & $*$ & 0.162 & & & $*$ & 0.094 & & & $*$ \\
\hline
\end{tabular}

Note: $1=$ over 15,$000 ; 2=10,001$ to 15,$000 ; 3=5,001$ to 10,$000 ; 4=5000$ and less

\subsection{Quality of Study and Capabilities of Graduates}

Several studies are developing the link between HEI sustainability and the capabilities of graduates (Thomas and Day, 2014; Sandri, et al., 2018). We focused on the economic aspects of HEI sustainability and tried to find an answer for a question, whether the subsidy model takes into account the perceived quality of study at public HEIs and the enquired capabilities of graduates. The results can be found in table 6 . Based on results we conclude there is no statistically significant relationship between the indicators of economic sustainability (AVG_ST; AVG_SE; AVG_SR) and the perceived quality of the study (QoS) and the capabilities of graduates (CoG). Hypothesis 2 was not confirmed.

Table no. 6: Multivariate Tests of Significance - Pillai's trace statistic (QoS; CoG)

\begin{tabular}{|l|c|c|c|c|c|}
\hline Effect & Pillai's & F & Hypothesis df & Error df & p level \\
\hline Intercept & 0.793 & 26.824 & 2 & 14 & $\mathrm{p}<0.001$ \\
\hline QoS & 0.066 & 0.491 & 2 & 14 & 0.622 \\
\hline CoG & 0.042 & 0.307 & 2 & 14 & 0.741 \\
\hline
\end{tabular}

No tested combination of variables is statistically significant (table 7). Results are in line with previous research (Disterheft, et al., 2015; Orr and Usher, 2018) dealing with the capabilities of graduates and the development of specific skill set oriented on assessment 
and perception of sustainability. Better integration of the dimensions of quality of study and capabilities of graduates can help in defining and establishing HEI's sustainability approaches on the institutional level and fostering a culture of sustainability at different types of HEIs.

Table no. 7: Tests of Between-Subjects Effects (QoS; CoG)

\begin{tabular}{|c|c|c|c|c|c|c|}
\hline \multicolumn{2}{|l|}{ Source } & $\begin{array}{c}\text { Type III Sum } \\
\text { of Squares }\end{array}$ & df & Mean Square & $\mathbf{F}$ & p level \\
\hline \multirow{3}{*}{ Intercept } & AVG_ST & 518.778 & 1 & 518.778 & 7.945 & $0.013^{*}$ \\
\hline & AVG_SE & 254.879 & 1 & 254.879 & 9.884 & $0.007 * *$ \\
\hline & AVG_SR & 46.400 & 1 & 46.400 & 5.097 & $0.039 *$ \\
\hline \multirow{3}{*}{ QoS } & AVG_ST & 1.105 & 1 & 1.105 & 0.017 & 0.898 \\
\hline & AVG_SE & 0.811 & 1 & 0.811 & 0.031 & 0.862 \\
\hline & AVG_SR & 0.023 & 1 & 0.023 & 0.002 & 0.961 \\
\hline \multirow{3}{*}{ CoG } & AVG_ST & 2.576 & 1 & 2.576 & 0.039 & 0.845 \\
\hline & AVG_SE & 0.675 & 1 & 0.675 & 0.026 & 0.874 \\
\hline & AVG_SR & 0.614 & 1 & 0.614 & 0.067 & 0.799 \\
\hline
\end{tabular}

\section{Conclusion}

The study theoretically contributes to the sustainability of HEI by proposing a general and a specific conceptual model of sustainability in HEI. General model is based on experiences, observation, interviews with top managers of 15 HEIs all over the world, and published research, while specific model links capabilities of graduates, employability of graduates, academic research, and financial funds in the context of quality of education, HEI reputation, and HEI budget. There exist some models of sustainability of HEIs, but our study revealed that all sustainability models must be considered very carefully even within a country. Sustainability of HEIs differs according to their orientation (technical, humanities, arts, business, medicine) and their ownership. There exist HEIs clusters (e.g. technical, arts, business, etc.) and HEIs within a cluster behave similarly towards sustainable management.

Our suggested models can help HEIs' managers in their strategical and tactical decision making in order to maintain and increase HEI's competitiveness. As for other practical implications, this study examined factors impacting the economic sustainability of HEI and it focused especially on the link between economic sustainability and the number of students, quality of research, quality of study and the capabilities of graduates. As the sustainability measures average shares on government subsidies (for teaching performance, research performance and total subsidy) for years 2009-2019 were used. Research results proved that the number of students and the productivity of research directly influence the economic sustainability of HEIs, while the quality of study and capabilities of graduates did not. Another practical implication is that the performance of the HEIs directly determines HEI s sustainability. The quality of study and the employability of graduates are perceived differently at the different types of HEIs so HEIs need to adopt different strategies to satisfy diverse stakeholders' expectations. This last finding is in accord with the studies claiming that different types of HEIs adopt different approaches to sustainability. 
While this study provides useful findings contributing to sustainable HEIs, it also has limitations that call for further research. The first restriction of fully applying our results is a context limitation and therefore perfect fit of our research results would be for central and eastern European countries, especially for the countries of Visegrad region (Slovakia, Czech Republic, Poland and Hungary). Furthermore, our findings can be found interesting by the policy makers in the countries, where the HEIs funding system is similar to the one applied in above mentioned countries. On the one hand suggested sustainability models are expected to work worldwide, but on the other hand they could better fit for smaller and medium-sized HEIs in developed economies or economies in transition. Research results might be slightly different in countries where funding system is based on capabilities of graduates and their immediate employability.

As we tested a specific model for HEI offering business programs, HEIs offering for example medicine or "research-oriented" HEIs might require some modifications of our models. Our models will not perfectly work in economies where HEIs are highly supported by state and where "know who" in more important than "know how". Further research could be focused on the impact of capabilities of graduates on HEI's reputation, but it should be based on employers' perceptions with links to a quality of learning, research and marketing communication of HEI, because grounded on our observations and interviews with colleagues and people from HR agencies in Slovakia and Czech Republic we know that employers underestimate students from private HEIs. It is more difficult for students from private HEIs to get a job than it is for students from public HEIs.

\section{Acknowledgement}

This work was supported by the Scientific Grant Agency of the MoESRS and of Slovak Academy of Sciences under the contract No. VEGA-1/0776/18.

\section{References}

Ahmad, M.M. and Elhuni, R., 2014. Critical quality factors for successful TQM implementation in Libyan oil and gas sector. Benchmarking: An International Journal. 21(5), pp.713-733.

Al Kharusi, S., and Sree Rama Murthy, Y. 2017. Financial sustainability of private higher education institutions: the case of publicly traded educational institutions. Investment Management and Financial Innovations, 14(3), pp.25-38.

Aleixo, A.M., Leal, S. and Azeiteiro, U.M., 2018. Conceptualization of sustainable higher education institutions, roles, barriers, and challenges for sustainability: An exploratory study in Portugal. Journal of Cleaner Production, 172, pp.1664-1673.

Alghamdi, N., den Heijer, A., and de Jonge, H., 2017. Assessment tools' indicators for sustainability in universities: an analytical overview. International Journal of Sustainability in Higher Education, 18(1), pp.84-115.

Amaral, L.P., Martins, N. and Gouveia, J.B., 2015. Quest for a sustainable HEI: a review. International Journal of Sustainability in Higher Education, 16(2), pp.155-172.

Angulo-Ruiz, L.F. and Pergelova, A., 2013. The Student Retention Puzzle Revisited: The Role of Institutional Image. Journal of Nonprofit and Public Sector Marketing, 25(4), pp.334-353. 
Angulo-Ruiz, F., Pergelova, A., Cheben, J., and Angulo-Altamirano, E., 2016. A crosscountry study of marketing effectiveness in high-credence services. Journal of Business Research, 69(9), pp. 3636-3644.

Appelbaum, S.H. and Patton, E., 2002. Downsizing the university: bonne chance!. The International Journal of Educational Management, 16(3), pp.126-136.

Barnes, N. J., \& Phillips, P. S. 2000. Higher education partnerships. International Journal of Sustainability in Higher Education, 1(2), pp.182-190.

Blanco-Portela, N., Benayas, J., Pertierra, L.R. and Lozano, R., 2017. Towards the integration of sustainability in higher education institutions: a review of drivers of and barriers to organisational change and their comparison against those found of companies. Journal of Cleaner Production, 166, pp.563-578.

Bratti, M., McKnight, A., Naylor, R. and Smith, J., 2004. Higher education outcomes, graduate employment and HEI performance indicators. Journal of the Royal Statistical Society: Series A (Statistics in Society), 167(3), pp.475-496.

Brown, W.O., 2001. Sources of funds and quality effects in higher education. Economics of Education Review, 20(3), pp.289-295.

Budur, T., Rashid, C.A. and Poturak, M., 2018. Students' perceptions on HEI selection, decision making process: A case study in Kurdistan Region of Iraq. International Journal of Social Sciences and Educational Studies, 5(1), pp.133-144.

Cantwell, B., 2019. Are international students cash cows? Examining the relationship between new international undergraduate enrollments and institutional revenue at public colleges and universities in the US. Journal of International Students, 512, pp.512-525.

Casarejos, F., Frota, M.N. and Gustavson, L.M., 2017. Higher education institutions: a strategy towards sustainability. Int. Journal of Sustainability in HE, 18(7), pp.995-1017.

Chebeň, J., 2013. The importance of the responsible management in public organizations. Economic Research-Ekonomska Istraživanja, 1(26 (sup2)), pp.167-178.

Ciaian, P., Lančarič, D. and Pokrivcak, J. 2018. The Productivity of Economics Research in Slovakia. Eastern European Economics, 56(2), pp. 168-200.

Cortese, A.D., 2003. The critical role of higher education in creating a sustainable future. Planning for higher education, 31(3), pp.15-22.

Čudanov, M., Jaško, O. and Săvoiu, G., 2012. Public and public utility enterprises restructuring: Statistical and quantitative aid for ensuring human resource sustainability. Amfiteatru Economic Journal, 14(32), pp.307-322.

Dabija, D.C., Dinu, V., Postelnicu, C. and Mihăilă, A., 2017. Stakeholders' Perception of Sustainability Orientation within a Major Romanian University. International Journal of Sustainability in Higher Education, 18(4), pp.533-553.

Dabija, D.C., Postelnicu, C., Pop, N.A. 2014. Methodology for Assessing the Degree of Internationalization of Business Academic Study Programs. Amfiteatru Economic, 16(37), pp.726-745.

De Araújo Góes, H.C., and Magrini, A., 2016. Higher education institution sustainability assessment tools. International Journal of Sustainability in HE, 17(3), pp.322-341.

De Boer, H., Jongbloed, B., Benneworth, P., Cremonini, L., Kolster, R., Kottmann, A. and Vossensteyn, H., 2015. Performance-based funding and performance agreements in fourteen higher education systems. Center for Higher Education Policy Studies. 
Dill, D.D. and Teixeira, P., 2000. Program diversity in higher education: an economic perspective. Higher Education Policy, 13(1), pp. 99-117.

Disterheft, A., Caeiro, S., Azeiteiro, U.M. and Leal Filho, W., 2015. Sustainable universities-a study of critical success factors for participatory approaches. Journal of Cleaner Production, 106, pp.11-21.

Dlouha, J., Henderson, L., Kapitulčinová, D. and Mader, C. 2018. Sustainability-oriented higher education networks: Characteristics and achievements in the context of the UN DESD. Journal of cleaner production, 172, pp.4263-4276.

Eger, L., Egerová, D. and Pisonová, M. 2018. Assessment of School Image. Center for Educational Policy Studies Journal, 8(2), pp. 97-122.

Epelboin, Y., 2014. MOOC 2014: should universities enter the competition? EUNIS Journal of Higher Education. 9p.

Farčnik, D. and Domadenik, P., 2012. Has the Bologna reform enhanced the employability of graduates? Early evidence from Slovenia. International journal of manpower, 33(1), pp.51-75.

Fath, B.D., 2015. Quantifying economic and ecological sustainability. Ocean and Coastal Management, 108, pp.13-19.

Findler, F., Schönherr, N., Lozano, R., and Stacherl, B., 2019. Assessing the impacts of HEI on sustainable development-an analysis of tools and indicators. Sustainability, 11(1), pp. 1-19.

Fonseca, A., Macdonald, A. Dandy, E. and Valenti, P., 2011. The state of sustainability reporting at Canadian HEIs. International Journal of Sustainability in HE, 12(1), pp.22-40.

Gora, A.A., Ștefan, S.C., Popa, Ș.C. and Albu, C.F., 2019. Students' Perspective on quality assurance in higher education in the context of sustainability: A PLS-SEM approach. Sustainability, 11(17), p.4793.

Hák, T., Janoušková, S. and Moldan, B., 2016. Sustainable Development Goals: A need for relevant indicators. Ecological Indicators, 60, pp.565-573.

Horn, A.S. and Lee, G., 2019. Evaluating the accuracy of productivity indicators in performance funding models. Educational Policy, 33(5), pp.702-733.

Jongbloed, B., 2010. Funding higher education: A view across Europe. Brussels: European Centre for Strategic Management of HEIs.

Jongbloed, B. and Vossensteyn, H., 2001. Keeping up performances: An international survey of performance-based funding in higher education. Journal of Higher Education Policy and Management, 23(2), pp.127-145.

Jongbloed, B. and Vossensteyn, H., 2016. HEI funding and student funding: international comparisons. Oxford Review of Economic Policy, 32(4), pp.576-595.

Lavery, M.R., Acharya, P., Sivo, S.A. and Xu, L., 2019. Number of predictors and multicollinearity: What are their effects on error and bias in regression? Communications in Statistics-Simulation and Computation, 48(1), pp.27-38.

Leal Filho, W., Skouloudis, A., Brandli, L.L., Salvia, A.L., Avila, L.V. and RaymanBacchus, L., 2019. Sustainability and procurement practices in higher education institutions: Barriers and drivers. Journal of Cleaner Production, 231, pp.1267-1280. 
Lozano, R., 2006. Incorporation and institutionalization of SD into universities: breaking through barriers to change. Journal of cleaner production, 14(9-11), pp.787-796.

Miao, K., 2012. Performance-Based Funding of Higher Education: A Detailed Look at Best Practices in 6 States. Center for American Progress.

Ong, B.S. and Grigoryan, A., 2015. MOOCs and universities: Competitors or partners? International Journal of Information and Education Technology, 5(5), pp. 373-376.

Orr, D. and Usher, A. 2018. 22 Revisiting student performance as a cornerstone of higher education: how is student performance reflected in performance-based funding? Research Handbook on Quality, Performance and Accountability in Higher Education, pp.290.

Pavelka, J., 2014. Trends emerging on the Czech Higher-education market and their influence on the employability of graduates in practice since 1989. Procedia-Social and Behavioral Sciences, 139, pp.87-92.

Sandri, O., Holdsworth, S. and Thomas, I., 2018. Vignette question design for the assessment of graduate sustainability learning outcomes. Environmental Edu.Research, 24(3), pp.406-426.

Teichler, U., 2009. Higher Education and the World of Work - Conceptual Frameworks. Comparative Perspectives, Empirical Findings (Global perspectives on higher education, Vol. 16). Rotterdam: Sense Publishers, Taipei.

Thomas, I. and Day, T., 2014. Sustainability capabilities, graduate capabilities, and Australian HEIs. International Journal of Sustainability in Higher Education, 15(2), pp.208-227.

Thomas, M. K. and Chabotar, K. J., 2015. Between Collaboration and Merger: Expanding Alliance Strategies in Higher Education. New York, NY: TIAA Institute.

Thune, T., 2011. Success Factors in HE - Industry Collaboration: A CS of collaboration in the engineering field. Tertiary Education and Management, 17(1), pp.31-50.

Vekić, A., Borocki, J. and Fajsi, A., 2019. Development of Entrepreneurial Ecosystem through University's New Companies. Management: Journal of Sustainable Business and Management Solutions in Emerging Economies, 24(3), pp. 33-45.

Velazquez, L., Munguia, N. and Sanchez, M., 2005. Deterring sustainability in higher education institutions: An appraisal of the factors which influence sustainability in higher education institutions. International Journal of Sustainability in Higher Education, 6(4), pp.383-391.

Weenen, Van H., 2000. Towards a vision of a sustainable university. International Journal of Sustainability in Higher Education, 1(1), pp. 20-34.

Woya, A.A., 2019. Employability among Statistics Graduates: Graduates' Attributes, Competence, and Quality of Education. Education Research International, (1), 7p.

Wright, T., 2010. University presidents' conceptualizations of sustainability in higher education. International Journal of Sustainability in higher education, 11(1), pp.61-73.

Yamamoto, K., 2004. Corporatization of national universities in Japan: revolution for governance or rhetoric for downsizing? Financial Accountability \& Management, 20(2), pp.153-181.

Zainordin, N. and Ismail, S., 2018. Sustainability assessment for higher education institutions: A review on strengths and weaknesses. AIP Conference Proceedings, $(2016,1)$, p. 020155. 